\title{
Club Goods and Post-Disaster Community Return*
}

\author{
Emily Chamlee-Wright and Virgil Henry Storr ${ }^{\dagger}$
}

\section{Contact Information:}

\author{
Emily Chamlee-Wright \\ Department of Economics \\ Beloit College \\ 700 College St. \\ Beloit, WI 53511 \\ Chamlee@beloit.edu \\ Virgil Henry Storr \\ Mercatus Center \\ George Mason University \\ 3301 N. Fairfax Dr. \#450 \\ Arlington, VA 22201 \\ vstorr@gmu.edu
}

\footnotetext{
* This paper was published in Rationality and Society, 21 (4) 2009. We would like to thank three anonymous referees, Peter Boettke, Peter Leeson, Scott Beaulier, Josh Hall, Charles Westerberg, Bob Elder, the participants in the American University Economics Department Seminar Series and the participants at the "Social Embeddedness of Economic Life" session at the 2008 Southern Economic Association meetings for their comments on earlier drafts. We would also like to thank the members of the research team who helped us conduct the interviews for this project, including Lenore Ealy, Dan Rothschild, Anthony Skriba, and Adam Martin. Additionally, we would also like to thank Kathryn Linnenberg for her assistance in training the interview team and developing the interview instrument; our Vietnamese interpreters Khai Hoang and $\mathrm{Vu}$ Nguyen; and Skyler Treat for her research assistance. Finally, we would like to thank the Mercatus Center for their generous financial support. The usual caveat applies.

+ Emily Chamlee-Wright is Professor of Economics at Beloit College and Affiliated Senior Scholar at The Mercatus Center, George Mason University. Professor Chamlee-Wright is author of The Cultural Foundations of Economic Development (Routledge) and Culture and Enterprise with Don Lavoie (Routledge). Virgil Henry Storr is a Senior Research Fellow and the Director of Graduate Student Programs at The Mercatus Center, George Mason University. Dr. Storr is the author of Enterprising Slaves and Master Pirates (Peter Lang). Drs. Chamlee-Wright and Storr are currently principal investigators with The Mercatus Center's project Crisis and Response to Hurricane Katrina. A description of the full project can be found at http://www.mercatus.org/Katrina.
} 


\title{
Club Goods and Post-Disaster Community Return
}

\begin{abstract}
Hurricane Katrina caused over one hundred billion dollars in property damage in the Greater New Orleans region. Although much attention has been paid to why particular communities have begun to recover and others have failed to rebound, very little attention has been paid to how the communities that have recovered actually went about doing so. This paper attempts to close that gap by examining how the church provision of club goods can foster social cooperation and community redevelopment in the wake of a disaster. In particular, we investigate the swift return of the community surrounding the Mary Queen of Vietnam (MQVN) Catholic Church in New Orleans East after Hurricane Katrina. Utilizing a unique bundle of club goods provided by the MQVN Catholic Church, residents in the New Orleans East Vietnamese-American community a) rebuilt their distinct ethnic-religious-language community, b) overcame the social coordination difficulties created by Katrina, and c) engaged in successful political action to protect their community.
\end{abstract}

Key Words: religious provision of club goods, community redevelopment, social resilience, post-disaster recovery

\section{Introduction}

[The] perpetual consumption and reproduction of capital affords the explanation of what has so often excited wonder, the great rapidity with which countries recover from a state of devastation; the disappearance, in a short time, of all traces of the mischiefs done by earthquakes, floods, hurricanes, and the ravages of war. An enemy lays waste a country by fire and sword, and destroys or carries away nearly all the moveable wealth existing in it: all the inhabitants are ruined, and yet in a few years after, everything is much as it was before.

- John Stuart Mill, The Principles of Political Economy. Book I, Chapter V, paragraph I.5.19.

Hurricane Katrina might have given even John Stuart Mill reason to doubt whether Gulf Coast communities would recover from the devastation that followed in her path. Indeed, at the present writing (three and a half years after the storm), some communities appear as though they might stand as shocking exceptions to Mill's optimistic thesis. ${ }^{1}$ And yet, in some communities, Mill's expectations of swift recovery have indeed been born out. The community surrounding the Mary Queen of Vietnam (MQVN) Catholic 
Church in New Orleans East, for instance, is widely considered to be a post-Katrina success story.

With the exception of the French Quarter, Garden District, and Uptown (which incurred little to no flood damage due to higher elevations), the MQVN neighborhood was amongst the hardest hit communities in New Orleans post-Katrina. Still, it came back faster and more robustly than virtually all other neighborhoods in Orleans Parish, even those with similar levels of flood damage, and those that were considerably more affluent. According to the Urban Land Institute (ULI), the principal consulting group advising the Bring New Orleans Back Commission, "The New Orleans East area experienced some of the city's most severe flooding, with flood depths ranging from five to more than twelve feet," (ULI 2006: 43). Early recommendations in the redevelopment planning process, in fact, suggested that its proximity to the Bayou Sauvage National Wildlife Refuge made New Orleans East a good candidate for conversion to open space (ibid.). By April 2006, however, 1,200 of the 4,000 residents who lived within a one-mile radius of the church had returned. Within a year of the storm, more than 3,000 residents had returned. By the summer of 2007, approximately 90 percent of the MQVN residents were back, while the rate of return in New Orleans overall remained at only 45 percent. ${ }^{2}$ Further, within a year of the storm, 70 of the 75 Vietnamese-owned businesses in the MQVN neighborhood were up and running. Sixteen months after the storm, on the other hand, only ten percent of the residents living in the affluent Lakeview neighborhood had returned; a threshold that the MQVN community had achieved within weeks of the storm (Bohrer 2007).

Much of the attention in the disaster research literature has focused on why certain communities are so vulnerable to disasters and on the barriers that stand in the way of recovery in these communities. Erikson (1994), Klinenberg (2003), Peacock et al. (1997) and Wisner et al. (2004), for instance, have discussed how institutional disregard for the poor and the elderly as well as structural racism has made some individuals and areas particularly vulnerable to disasters ranging from flooding and fires to heat wave associated deaths. Focusing on Katrina, Colten (2006), Dyson (2006), powell [sic] et al. 
(2006) have argued that the long history of racial segregation in public housing in New Orleans and private real estate markets that concentrated poor black communities in low-lying areas like the Lower Ninth Ward explains why members of this demographic group were amongst the hardest hit. Similarly, BondGraham (2007) argues that city planners intentionally make it harder for poor residents to return so as to externalize the costs of providing services for the poor to other municipalities and states. And, Bosman et al. (2007: 21) have argued that redevelopment planning initiatives continue a historical pattern in which "African-Americans have been pushed out of their homes, or forced off the land they once occupied." There is a consensus emerging in this literature that the communities that are most likely to successfully weather and recover from disasters are those that are economically and politically advantaged prior to the disaster. $^{3}$

The MQVN community, however, was not particularly wealthy nor did it posses a great deal of political clout prior to Katrina. ${ }^{4}$ Its success thus presents something of a puzzle. How did this community engineer such a rapid recovery? How did it recover more quickly than communities that suffered less damage, were wealthier and/or were politically more powerful?

A full response to this question would include an examination of the wide array of social resources embedded within this Vietnamese-American community. As we argue elsewhere, for instance, many members of the community overcame considerable hardship when they emigrated from Vietnam to New Orleans and could draw on this collective narrative as they faced the challenge of recovering from Katrina (ChamleeWright and Storr 2008). In this article, we focus on the critical role played by the MQVN Catholic church in the redevelopment effort. Specifically, the MQVN church provided a unique bundle of club goods that fostered social cooperation and community rebound in the wake of disaster. Utilizing this bundle of club goods, residents in the New Orleans East Vietnamese-American community a) rebuilt their distinct ethnic-religious-language community, b) overcame the social coordination difficulties created by Katrina, and c) engaged in successful political action to protect their community. Neither the theory of 
clubs literature nor the disaster recovery literature draws this critical link between club goods and community redevelopment; none stress the role that club goods play in helping communities overcome the collective action challenges associated with postdisaster community recovery. This paper also hopes to complement an already welldeveloped theory of clubs literature by highlighting more generally the role that club goods can play in rendering individual agency in adverse conditions more effective.

\section{A brief history of MQVN community}

The MQVN community was founded by refugees from three North Vietnamese villages. The division of Vietnam in 1954 set off a wave of migration from North to South Vietnam, particularly from Catholics and those aligned with the French colonial regime. Catholics from the Bui Chi province and two other northern villages fled en masse to the coastal town of Vung Tau (Zhou \& Bankston 1994). With the fall of Saigon in 1975 approximately 1,000 residents of Vung Tau fled again, this time for the United States. Through Associated Catholic Charities, this first wave of refugees were established in Versailles Village Apartments in New Orleans East, a poor (and by then) predominantly African-American community. The later waves of Vietnamese migration to this area were a spontaneous outgrowth of this initial settlement. Drawn by ties to friends and family, another 2,000 Vietnamese arrived in 1976 alone, and migration continued through the 1980s (Bankston \& Zhou 2000).

By 1980, many Vietnamese had moved out of the Versailles Village Apartments and into single family homes located or built within the same neighborhood. Though the community as a whole was still relatively poor, wealth continued to accumulate in the neighborhood with higher-end housing developing alongside more modest bungalows (ibid.). As the pattern of Catholic migration continued, the community quickly outgrew the small chapel originally provided for their use, and in 1980, petitioned the Archdiocese for permission to build a much larger church, with capacity for 6,000 parishioners. By 1985, the Mary Queen of Vietnam Church 
was built with funds raised from Vietnamese Catholics in the local neighborhood and across the greater New Orleans area. ${ }^{5}$

In 2003 Father Vien Nguyen became Pastor of the MQVN parish, supported by two other priests and five paid staff members. Like the MQVN priests before him, Father Vien emerged as both the religious and de facto civic leader, supported by other key members of the community of high social and/or socio-economic status (ibid.).

By August of 2005, the MQVN neighborhood was a vibrant and wellfunctioning community. The church regularly served as host to Vietnamese cultural events, weekly farmers markets, and a periodic arts and crafts market that drew crowds from across the city. Though median incomes still remained below that of Orleans Parish, home ownership rates within the community grew from less than $3 \%$ in 1980 to nearly $40 \%$ in $2000 .{ }^{6}$ By 2005 , the church had taken the lead in advancing an ambitious set of community redevelopment projects, including "VietTown" (a Vietnamese cultural and commercial center), revitalization of the two Vietnamese shopping centers in the community, the establishment of an urban gardening project, and the building of a housing development for the elderly adjacent to the church. The lay leadership within the church was also wellorganized and robust, with key community members taking responsibility for organizing specific block grids within the neighborhood. The community remained socially and politically insular, however, with leaders preferring to attend to the issues within rather than beyond the community.

The MQVN church was (and remains) the hub around which spiritual, social, and commercial life evolved. Father Vien estimates that "of the 4,000 people within a onemile radius of the church pre-Katrina, at least 3,800 of them are Catholic."7 Located at the physical center of the neighborhood, the church is within walking distance for most members of the community. Though there are two other Vietnamese Catholic churches in New Orleans, MQVN is the most deliberate about preserving the Vietnamese character of the church, with Vietnamese Mass offered twice daily. ${ }^{8}$ Further, the MQVN 
neighborhood has a much higher concentration of ethnic Vietnamese people than any other residential area in New Orleans.

The de facto community center of the neighborhood, the church, its rectory and its classroom building provide the principal social space in the community. When we asked residents to tell us about places they would frequently meet with friends or engage in community gatherings, "the church" was the overwhelming response. ${ }^{9}$ Nonreligious civic life was clearly grounded within the church community, with the church housing a wide variety of civic groups and social service organizations. Further, networks of commercial life radiated from the MQVN hub (ibid.). The 75 Vietnameseowned businesses in the area, including grocery stores, traditional medicine shops, restaurants, pharmacies, doctors, lawyers, accountants, etc., were also all within walking distance of the neighborhood center. And according to Father Vien, almost all the business owners in the area were connected to the MQVN church, estimating that, "of all the businesses [in this community] there may be two or three business owners who are not Catholic."

When Hurricane Katrina hit, Father Vien stayed behind with those who did not evacuate. Approximately 500 people rode out the storm overnight on Sunday August $28^{\text {th }}$ and through the next morning at the church's school building. After the storm had passed and thinking the worst was over, most of the residents began returning to their homes to check for damage. By 2:30 Monday afternoon, about three inches of water covered the streets. By 5:30 PM the waters were rising rapidly. Using boats and cell phones, Father Vien began to round up residents again, returning them to the second floor of the church's school building.

Following the evacuation, Father Vien traveled to evacuation sites in Louisiana, Texas, Georgia, and Arkansas to check the status of his parishioners and to convey information about family members. Along the way he took digital photographs of every member of the community he met to confirm their safety to loved ones in distant cities. But concern quickly turned to the return. Father Vien and the lay leadership of the community organized themselves to stage the first phase of what 
would become a steady march toward the near complete redevelopment of the community within two years. Their success raises questions about the logic of postdisaster community return and the role that the club goods provided by the church played in bringing about recovery.

\section{The logic of post-disaster collective action and the church provision of club goods}

Disasters, particularly those of the scale of Hurricane Katrina, present a daunting challenge for displaced individuals. The decision to return and rebuild their damaged or destroyed home is a costly one and one for which the benefits of rebuilding are necessarily uncertain. Whether returning and rebuilding makes sense depends on whether their displaced neighbors also return and rebuild. In such a scenario, the rational move for any particular displaced individual may be to wait and see what their neighbors are going to do. The risks associated with being the first mover are arguably prohibitive. Since every displaced resident faces a similar calculus, community recovery (i.e. the return and recovery of residents) after a disaster is a very real challenge.

Modeling this scenario is straightforward. This scenario can be modeled as a two player single-shot game under conditions of imperfect information. Consider a community comprised of two families whose homes were destroyed by a disaster and were subsequently displaced to different locations. Or, view these players as representative disaster victims or as groups of disaster victims who have been displaced to different locales. The key feature is that communication between the players is impossible so that they cannot form reasonable expectations about the other's decision making. That information and regime uncertainty is also likely in post-disaster environments further complicates a player's ability to guess at the other's likely behavior. ${ }^{10}$ Players A and B both face a decision of whether to return and rebuild their old homes or to establish new lives in the community where they have resided since the disaster. Both also have imperfect information about the other player's intentions. If they both decide to return then they each earn a payoff of $\alpha$. Any player that does not 
Figure 1. Return game with imperfect information

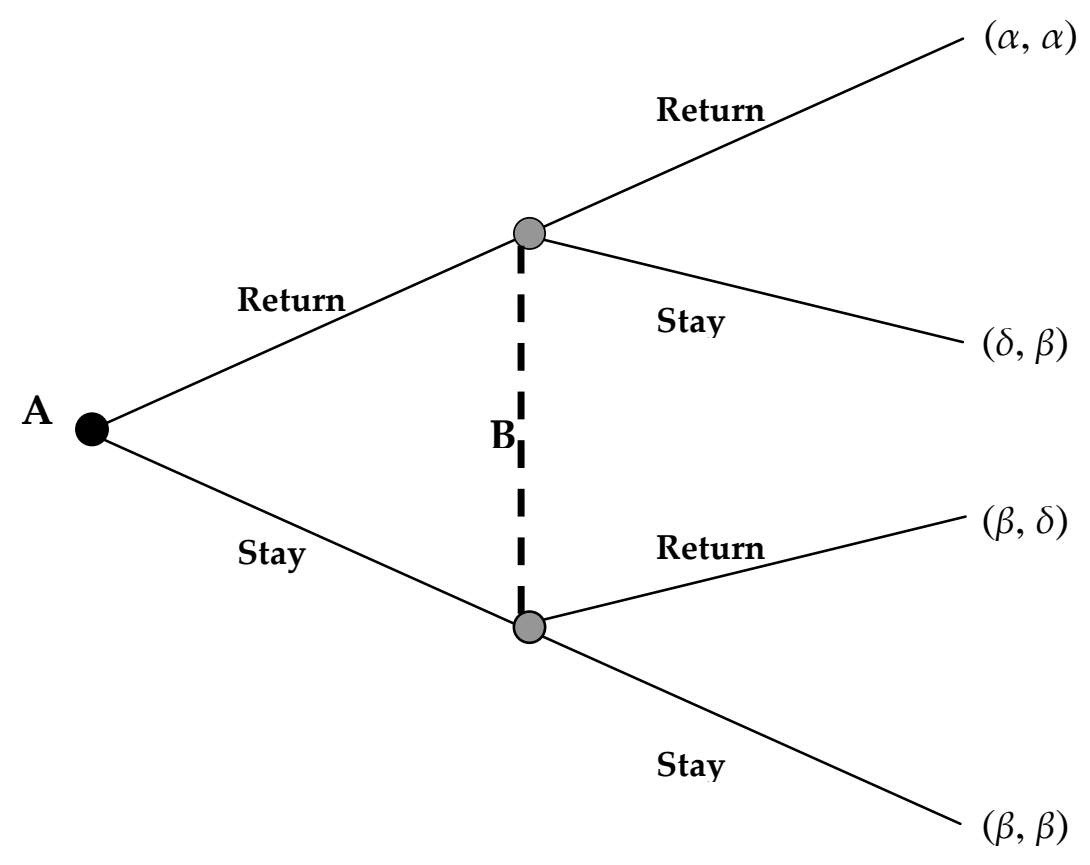

return earns a payoff of $\beta$, where $\beta<\alpha .{ }^{11}$ If either player decides to return but is the sole returnee, that player earns a payoff of $\delta$, where $\delta<\beta .{ }^{12}$ Under these conditions, both players returning to rebuild would be the socially optimal outcome, since by assumption $\alpha>\beta>\delta$ and $2 \alpha>2 \beta>\delta+\beta$. See Figure 1 for a representation of this game in extensive form.

Given that both players have imperfect information about what the other player is likely to do, the strategy that dominates will depend on whether the expected value of returning is greater or less than the payoff from remaining in the new locale. Assuming that the expected value of remaining in the new locale is greater than the expected value returning under conditions of persistent uncertainty, then remaining in the new locale will be the dominant strategy. That is, assuming that $\beta>\alpha \mathrm{p}_{\mathrm{r}}+\delta\left(1-\mathrm{p}_{\mathrm{r}}\right)$, where $\mathrm{p}_{\mathrm{r}}$ is the probability that the other player will return, not returning will be the dominant strategy. Since $2 \alpha>2 \beta$, the strategy of remaining displaced is socially suboptimal. 
Figure 2. Return game with the aid of the church

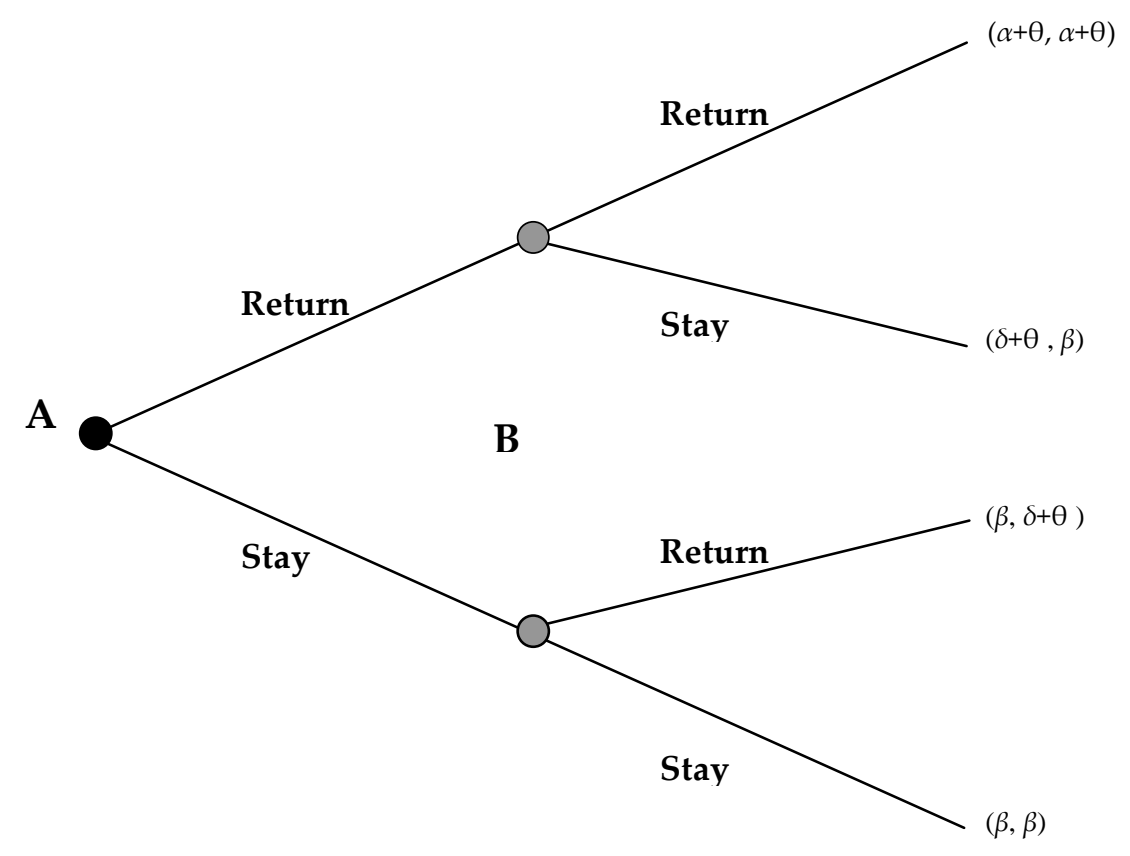

This poses a serious challenge for displaced residents. In order to obtain the socially optimal outcome the families would have to locate one another and then credibly commit to returning. Finding where your neighbors were relocated after a disaster and obtaining credible commitments from them that they will return is extremely costly if not impossible. This is true in the two player game depicted in Figure 1. This challenge is even more severe the larger the number of families in the community displaced by the disaster and the further widespread the evacuation destinations.

Religious organizations and other community based clubs, however, can provide a bundle of club goods in the form of an organizational structure for coordinating the activities of members, information about other displaced members of the community and appropriate forms of support that both allows members to coordinate their return and lowers the costs of returning and rebuilding.

This new game is depicted in Figure 2. The religious organization can keep track of displaced residents and can coordinate their return, effectively eliminating the 
uncertainty about the other player's intentions. In other words, the religious organization can increase the probability that the other player will also return (i.e. $\mathrm{p}_{\mathrm{r}}$ increases), which would raise the expected value of returning. If the church is extremely effective it can create a scenario where the expected value of returning trumps the expected payoff from not returning (i.e. $\beta<\alpha \mathrm{p}_{\mathrm{r}}+\delta\left(1-\mathrm{p}_{\mathrm{r}}\right)$ ). The religious organization also assists returning residents by providing charitable aid $\theta$, so that returning residents receive their original payoff ( $\alpha$ or $\delta$ ) plus $\theta$. Community return and rebuilding, thus, depends on whether the players are convinced by the religious organization that the return of their neighbors is likely and whether the religious organization provides the necessary aid. If either $\delta+\theta>\beta$ or the religious organizations involvement is sufficient to convince either player that community rebound is likely (i.e., that $p_{r}$ is sufficiently high so that $\left.\beta<\alpha \mathrm{p}_{\mathrm{r}}+\delta\left(1-\mathrm{p}_{\mathrm{r}}\right)\right)$, then return will be the dominant strategy. By providing ethnically and linguistically appropriate aid to displaced members of the community that might not have otherwise been available to them and a bundle of other club goods including an organization structure that could be used to facilitate collective action, the MQVN Catholic Church fostered the rebound of the New Orleans East VietnameseAmerican community after Hurricane Katrina.

That club goods can be key for community redevelopment after a disaster and the role they play in rendering individual agency more effective is not discussed in the theory of clubs literature. Instead, the focus in that literature has been on how clubs of varying sizes, organizational structures and membership demographics overcome collective action problems relying of various monitoring strategies and incentive systems in order to provide quasi-public goods. ${ }^{13}$

Buchanan (1965) and Olson (1965) are widely recognized as seminal works in the theory of clubs. Buchanan's (1965) insight was that many valuable goods and services are neither purely private goods nor are they purely public goods. Recall from Samuelson (1954) that purely public goods are non-rivalrous (i.e. person A can consume it without preventing an unlimited number of others from simultaneously consuming it) as well as non-excludable (i.e. it is not possible to prevent people who have not paid 
from consuming it). Purely private goods, on the other hand, are both rivalrous (i.e. if person A consumes it person B cannot also consume it) and excludable (i.e. person A can be made to pay for consuming the good). Buchanan recognized that few goods meet the strict criteria of a purely public good along the lines that Samuelson (1954) suggests and that a number of the goods traditionally thought of as public goods can be provided by clubs (i.e. exclusion is possible). In fact, Buchanan points out that common experience suggests that people often prefer club goods (e.g., membership at a community swimming pool) over purely private goods (e.g., a swimming pool in the backyard).

Similarly, Olson (1965: 36-43) recognized that organizations exist to further the common interests of their members through the joint provision of collective goods. He distinguished between inclusive groups, which jointly produce non-rivalrous collective goods and so do not need to restrict membership, and exclusive groups, which must restrict membership since they produce impure public goods that would suffer from overcrowding. Olson (ibid.: 35), however, observed that as groups grew larger they tended to provide less optimal levels of the collective good. And, he noted that group size and the level of coordination and organization needed are positively correlated when the provision of a collective good requires members to act simultaneously (ibid.: 43-52).

Buchanan' s theory of clubs and Olson's theory of collective action have much in common and both have been extended in a number of ways (Cornes and Sandler 1996). Recently, Dasgupta \& Kanbur (2007), for instance, have argued that "ideologies of community solidarity" in ethnic and religious communities which provide exclusive goods can actually "trump" the incentives that the poorest in those communities have to support redistributive policies (see also Dasgupta \& Kanbur 2005a and 2005b). Others have applied this theoretical lens to examine the provision of club goods by religious organizations and communities. Kuran (2001), for instance, describes how Middle Eastern Islamic waqfs provided water services, light houses, hospitals, orphanages, and public spaces as a means of acquiring a credible commitment from the state to enforce property rights and not predate against immobile private assets. In their study of the 
economic organization of the medieval church, Ekelund, et al. (1996) note that in addition to providing many private goods, the Church also provided essential public goods, such as a system of law and courts, and exerted its "transnational influence to limited armed conflict among petty warlords who dominated the political landscape of western Europe" (ibid.: 25). Further, the Church supplied club goods such as formal education and institutions that aided the poor (ibid.).

Additionally, Iannaccone $(1992 ; 1994)$ argues that many apparently non-rational acts committed by the religious faithful are rendered reasonable and intelligible once it is understood what role club goods can play in mediating the relationship between religious groups and their members. By providing club goods, religious groups can more effectively call upon members to make sacrifices, such as prohibitions on the use of alcohol and other worldly pleasures. In turn, such prohibitions serve as an efficient way to limit access to the club goods offered within the church. He further argues that strict religious groups are actually stronger than less strict groups and can increase the value of the goods they offer because strictness (e.g. clothing and dietary restrictions) reduces free riding allowing groups to differentiate between members whose participation is likely to be marginal and those who are likely to be committed. Berman $(2000,2003)$ has likewise argued that the religious provision of club goods can also explain destructive behavior among radical militia groups. Members who engage in violent acts cut off outside options, increasing their ability to credibly commit their loyalty to the group. This, in turn, limits access to those devoted to the cause.

Although there is now a quite extensive theory of clubs literature and even several studies which apply this theoretical lens to examine the provision of club goods by religious organizations, few studies have used this framework to study ethnic churches as inclusive, multi-product, multi-generational clubs which provide highly specific ethnic services. ${ }^{14}$ Similarly, no studies have looked at how the church provision of club goods can foster social cooperation and community rebound in the wake of a disaster. The logic presented here suggests important new territory in which club goods theory can lend insight to the social coordination problems post-disaster contexts present. In 
Section 4 we examine how this logic is born out by qualitative empirical analysis of the MQVN community.

\section{The provision of club goods in the MQVN community}

... your identity, your community, your culture, your life, your heritage can all be had here in this place.

$-\mathrm{Paul} \mathrm{Cao}{ }^{+}$

The analysis presented here is part of a larger study deploying both theoretical and qualitative analysis of rebound and recovery in the aftermath of Hurricane Katrina. The research team conducted more than 350 in-depth interviews between February 2006 and August 2008. Forty of the interview subjects are residents, business owners, and community leaders in the Vietnamese-American community in New Orleans East. These interviews, most of which were conducted in October 2006, provide the basis for the analysis presented here. ${ }^{15}$

When the first residents returned to New Orleans East just a few weeks after the storm, the circumstances were anything but hospitable. There was no access to clean water, no electrical service, none of the area businesses were open, the contents of the homes and businesses had been festering for weeks, and the mold was advancing by the day. The extreme conditions of post-Katrina New Orleans in these early weeks might give reason to doubt arguments that emphasize the rationality of the faithful (Iannaccone 1992, 1994; Kuran 2001; Berman 2000, 2003). The willingness to take on the disproportionate costs of an early return might instead be viewed as non-rational deference to the authority vested in the parish priest. And a selective reading of the interview transcripts might support this view. Reflections like those offered by Chinh $\mathrm{Do}^{+16}$ are common:

Chinh Do+: Father Vien, he's why we're staying. He put this community back together. He's a powerful man, too. The way he sounds, it's like he knows. We believe in him and we trust him too. What he says, we do it. 
And yet, the interview transcripts also demonstrate that far more is going on here than an uncritical deference to church authority.

Specially, MQVN was an inclusive, multi-product, multi-generational club which provided a bundle of highly specific culturally and linguistically appropriate club goods that fostered return. These goods included (i) Vietnamese language religious services, (ii) Vietnamese language training, (iii) occasional weekend markets for selling Vietnamese produce, arts and crafts, (iv) a space where members of the community could socialize (v) meeting spaces for religious and non-religious Vietnamese groups, (vi) an organizational structure that facilitated social coordination, (vii) community leadership that served as a focal point for community action and (viii) ethnically appropriate charitable aid. Additionally, several Vietnamese-American business owners belong to the church and provide members of the neighborhood with ethnicallysensitive goods and services (e.g. Vietnamese grocery stores, Vietnamese-language medical, legal and financial services, etc.). Again using these club goods, residents in the New Orleans East Vietnamese-American community a) rebuilt their distinct ethnicreligious-language community, b) overcame the social coordination difficulties created by Katrina, and c) engaged in successful political action to protect their community.

\section{a. Rebuilding the ethnic-religious-language community}

From the beginning, MQVN has taken on a distinctly cultural, as well as religious mission. The former pastor Father Francis Bui, for instance, has said that "We have the Vietnamese church to preserve Vietnamese culture and to pass on the language. If it wasn't for that, we could just assimilate into other churches for religion" (Bankston \& Zhou 2000: 460). Specifically, the MQVN church has provided its members a bundle of club goods including Vietnamese language religious services, Vietnamese language training and occasional weekend markets for selling Vietnamese produce, arts and crafts that allowed members to create a highly specific ethnic-religious-language community prior to Katrina. This community radiates beyond the physical structure of the church to the neighborhood blocks of homes and businesses that surround it. After the storm, 
this bundle of goods proved critical to attracting displaced residents back to New Orleans and to their rebuilding the community. Or, in terms of the logic presented in Section 3, the MQVN church provided ethnically and linguistically appropriate aid (i.e. it contributed to $\theta$ ) which significantly increased the magnitude of the payoffs associated with returning whether or not others return. ${ }^{17}$

The existence of a rich network of ethnic-religious ties within the MQVN community was well-documented long before Katrina. In particular, Bankston \& Zhou (1995, 1996, 2000) and Zhou \& Bankston $(1994,1998)$ emphasize the role the bundle of club goods provided by MQVN played in the integration of Vietnamese-American youth into the community and their academic achievement (see also Caplan et al. 1989, 1992; Rumbaut \& Ima 1998). Among other benefits, the regular religious services in Vietnamese, Vietnamese language instruction and the networks of support provided through the church, results in the neighborhood youth having a sense of "Vietnameseness" that enabled them to avoid the temptations and pitfalls that many poor minority children frequently face. In particular, "frequent church attendance leads to greater 'Vietnameseness,' and greater 'Vietnameseness,' by making young people subject to the network of supports and constraints of the Vietnamese community, leads to behavior conducive to upward mobility" (Bankston \& Zhou 1996: 31). ${ }^{18}$

The elderly, in particular, appear to place a premium on the distinct offerings of the MQVN Catholic Church.

Danh Tran': [I]n this community, old people tend to be more religious. They want to go to church everyday. In other places, there are churches too, but they are far away, and these people don't have any means of transportation to get there. Their children can only take them to church once or twice a week. They cannot take the elders there often.

Daily church attendance is normative among retired members of the communitysomething most elders can achieve on their own by taking the short drive or by walking. After Katrina, MQVN lobbied to have a FEMA trailer site for its elderly residents 
established directly opposite the church. This made the daily commute for religious services shorter still.

But MQVN did not just provide its members club goods that gave them the opportunity to build a distinctly Vietnamese Catholic spiritual life. It also provided them with club goods that allowed them to build a distinctly Vietnamese social life that made a rather ordinary neighborhood a special environment.

Hoa Duangt: Before Katrina, we Vietnamese people met each other everyday.

We go to church. On weekends, we go to church in the morning and in the evening, we get together and dine. We spend the whole day together.

When we asked people who they generally spend time with and how they know them, almost all of the respondents reported that outside of family, their primary social relationships are with other members of the church community.

In addition to networks of friendship that radiate out from the MQVN hub, the network of Vietnamese vendors and professionals is central to the ease of daily existence and overall quality of life. ${ }^{19}$

Lien Huynh': I go to the grocery store pretty often. I walk there all the time.

Besides, I don't have any vehicles. I also go to the open market. There are also a pharmacy and a doctor's office nearby.

The reopening of two of the three Vietnamese grocery stores made life within the nearby FEMA trailer park bearable, even enjoyable to some. The proximity of these stores is particularly important as many of the trailer occupants do not drive or lost their vehicle as a consequence of the flood.

The local business community provides not only the necessities of daily existence; it extends the social space provided by the church, expanding the physical and social context in which the ethnic-religious-language community can thrive. One of the routines missed most in the months following the storm was the Saturday morning open air market held outside one of the main retail strips. The owner of a local shop recalls the first days that the market reopened in the summer of 2006. 
Nhu Pham+: We were just wondering whether there's anything at all in the market. In the beginning, it was just like a social place where the women meet and socialize. After about three months, there have been some goods, some fruits and vegetables, trees, and plants...It's fun there every morning... On Saturday morning, there were a lot of people there...There were more than a hundred. There were fish and shrimp. People from different places bring them here. Because on the radio, they announce that this market is now open. So people start to bring stuff in. It's fun there. Some people only have a few bundles of vegetables and yet still they come to market as early as 5:00 in the morning.

While ordinary times afford the luxury of taking the bundle of club goods provided by MQVN for granted, the uniqueness of its offerings and their importance to (re)establishing the particular character of this community and reestablishing each member's quality of life became clearer following the storm. High concentrations of Vietnamese-Americans in other cities helped provide relief and assistance following the storm, but the unique qualities and characteristics of the MQVN were still missed.

Danh Tran': [We came back] because we are all Vietnamese. This place is like our second homeland. So we have to come back to rebuild the place.

Interviewer: Did you ever think of not coming back?

Danh Tran: As long as I'm alive, I will stay here. ...Sometimes people get sick of this place. So they leave. But after a while, they come back. They went to Houston and other places [after Katrina]. Many of them go there and come back.

Elderly members of the community were among those who found adjustment to life in other cities particularly difficult. Additionally, they did not find churches or other organizations in these cities that provided the ethnic club goods that are necessary to (re)create the sort of ethnic-religious-language community that exists in the MQVN community. By extension, younger family members also benefit from the social 
connectivity the MQVN community affords their elderly parents and grandparents. Expectations of support are extremely high within the Vietnamese-American family even under normal circumstance (Haines et al. 1981; Kibria 1994). After the storm, the weight of these obligations increased significantly.

Theresa $\mathrm{Cao}^{+}$: And I could have stayed [in Texas] but knowing that my parents' heart is here, I decided to come back. And my father, the reason for him to come back is that he doesn't know English and he felt that it would be so difficult for him to find employment in a new state. ... In Texas, he felt like he was a handicapped person. He was disabled.

Within the context of New Orleans East, Cao's parents were respected independent members of the community. Though her parents spoke little English and had little formal education, they led productive lives. Her father worked as a skilled laborer. Her mother independently navigated through the tasks of daily life. Once stripped from the context of New Orleans East, however, Cao's parents lost their independence and a good deal of their social status. As Cao says, they felt "handicapped" and "disabled." By helping her parents move back to the MQVN neighborhood, Cao helped to restore her parents' sense of independence and simultaneously reduced the burden their lack of independence placed upon her.

In sum, despite the hardships associated with an early return, the displaced members of the MQVN community have compelling reasons to come back and rebuild their lives in New Orleans East. The bundle of club goods provided by MQVN are critical to their being able to live spiritually full, socially connected, and independent lives.

\section{b. Overcoming the social coordination difficulties created by Katrina}

The church is basically the center, it's the heart of the community...Anything you want to do, you have to go through the church. 
In addition to providing club goods critical to the establishment (and redevelopment) of an ethnic religious community, the church also provides club goods in the form of meeting spaces for religious and non-religious Vietnamese groups and an organizational structure that facilitates the social coordination necessary to align the interests and activities of religious and secular life. This was certainly the case before Katrina. Priestly authority in both church and neighborhood matters, the structure of pastoral care, and overlapping networks of religious and secular activities were characteristic of life in this community pre-Katrina (Bankston \& Zhou 2000), and combined fortuitously to facilitate a swift en masse return post-Katrina.

The coordinating capacity of the MQVN priesthood was perhaps best demonstrated by the community's response to the early calls to worship following the storm. On October 23rd former MQVN Pastor and now Bishop Dominic Mai Luong returned from Orange County, California to hold a special Mass. More than two thousand parishioners were in attendance. Given the ghost-town feel of most New Orleans neighborhoods at this point of the recovery process, this turnout was seen as a clear sign of the community's intention to return, even though most of the people in attendance had to travel a considerable distance. Clearly, part of the coordinating capacity stems from the authority vested within the priesthood. Comments like the following are representative of the widespread (though good natured) deference to Father Vien's authority. ${ }^{20}$

Andrew Huynh ${ }^{+}$: [Father Vien] has the power that everyone listens no matter [what]-I hear people say behind his back that they won't listen to him. [But] when you're in front of him, you can't say no to him... Whatever he says, you say, "Yes Father. We'll get it done."

As important as this "authority effect" is, however, the "signaling effect" is an essential complement in the effort to coordinate a mass return (Chamlee-Wright 2008). ${ }^{21}$ Or in terms of the logic presented in Section 3, the organizational structure of the MQVN church increased the probability that many if not all displaced residents would return, raising the expected value of return for any displaced resident. By holding services so 
early on and making judicious use of media attention, Father Vien was able to signal that the New Orleans East community was not suffering from the collective action problem facing many other communities.

Mathew Nguyen+: After that Mass... we all [went] home and we started to contact each other from Houston, and all over the place. So it all got solved.

Priestly authority seems to have played a double role. Deference to Father Vien's calls for rebuilding directly impacted people's decisions. In turn, because people were confident that others would heed the pastor's call to return, they felt more assured that they would not be the only ones to return. This community was able to achieve the socially optimal outcome (i.e. community redevelopment) because MQVN's organization structure and Father Vien's priestly authority (conveyed through this structure) facilitated displaced families locating one another and convincingly committing to return. Or in other words, the church provided club goods that effectively converted the game depicted in Figure 1 to the game depicted in Figure 2. MQVN was thus vital in helping displaced community members overcome the collective action problem that they faced after Katrina.

It is important to point out, however, that rebuilding is moving ahead, not just because of priestly authority. Priestly authority is rather a complementary force that enhances a more dispersed system of social action, much of which lies beyond the dayto-day oversight of the priest. The physical and social infrastructures provided by the MQVN church all but erase the social distance between religious and secular civic life, and the social coordinating capacity we expect to find within the church generously spills over into non-religious civic life.

Before Katrina, lay leadership within the MQVN Catholic Church, primarily in the form of the Pastoral Council, played an important role in fundraising, celebrations, and church policies (Zhou \& Bankston 1994). Further, the neighborhood grid system of pastoral care ensured a high degree of overlap between church and neighborhood concerns. After the storm, this system provided a ready-made social infrastructure through which they were able to organize a mass return. 
Germaine $\mathrm{Ngo}^{+}:$... this community, even way before Katrina already had that organization piece in place. So, this community, the church is the center for everybody... And Father Vien had-and when I say Father Vien, even before Father Vien-we [had] the organizational step right... like for instance [we] have the Pastoral Council. Remember, in the Pastoral Council [we] have people who are in charge of different areas in the community... So, I mean all that Father Vien has to do is just call the Pastoral Council. The Pastoral Council will call all the different people, who are in charge of certain areas and those people call [the people in their area] and so that's why even when they were in different areas [after the storm] they knew exactly where everybody was.

Though Father Vien's authority was essential in organizing a mass return of the community, such an attempt would have been impossible if not for the coordination capacity of the lay leadership at each evacuation site and the organizational structure that connected these lay leaders to Father Vien, to one another and to their charges. Father Vien could not be in six cities at once, nor could he possibly manage the detailed plans that were unfolding on the ground.

Upon their return, for example, it was again the lay leadership within the community who provided relief supplies for the earliest returnees. This was critical because government and non-profit emergency relief organizations were not adequately providing culturally and linguistically appropriate aid after the storm.22

Interviewer: Where were you getting food that first weekend [you returned]?

Fr. Luke Nguyen: I went with a-how do you call-a pillar. I call him a pillar of the church....[T]wo men, Mr. [X] and the other man is Mr. [Y]. They belong to a group called Lingning pangtom. Lingning pangtom is the adult group, the [elders] of the parish... They belong so that anything needed in the parish, they go to do it. They are the pillars of the church... These two men here, plus the head of the council, Mr. [Z]. They are the pioneers who come back and rebuild, and they are the one that helped the community and so they're the answer. Without them, I don't know how we can call our people back because we can 
think, we can utilize, we can strategize together with them but they are the workers. They pursue what the goals are.

In short, the relationship between priestly authority and lay leadership is reciprocal, each requiring the other to be effective. Church leaders were able to organize and mobilize a widely scattered population by working through the Pastoral Council and less formal sources of lay leadership. In turn, the lay leadership was able to persuade people to respond because they had the moral force of the church behind them. Additionally, relying on the organizational structure of the church, parishioners were able to receive linguistically and ethnically appropriate aid which lowered the cost of return making it more likely.

The coordinating capacity of the church is expanded further by the high degree of overlap between leadership within the church and formal secular civic activities. PreKatrina, the church facilities served as the community center, providing space for afterschool tutoring, English language instruction, Vietnamese language classes, youth leadership development, and business development. And, given the shortage of meeting space following the storm, the church's provision of civic space has become all the more important. This common physical space creates opportunities for intersecting social networks to develop. The Boards of Directors of the National Alliance of Vietnamese American Service Agency (NAVASA), Vietnamese Initiatives in Economic Training (VIET), the Community Development Corporation (CDC), and the VietnameseAmerican Youth Leaders Association (VAYLA), for example, (all housed at the church) frequently overlap with each other and with the Pastoral Council. ${ }^{23}$

The overlap is not just a matter of post-Katrina convenience but the extension of a pre-Katrina pattern of strategically deploying social capital resources within the religious community toward secular ends. In describing the overlapping membership between the Vietnamese Educational Association (VEA) and the church, Bankston \& Zhou (2000: 460-461) quote one of the VEA directors as saying, "we formed the Education Association among the people of the church, at first. We wanted a way to carry on Vietnamese culture and we wanted to help our young people do well in 
American schools. We knew that we could only accomplish these things by working together."

In the months following the storm, the church was the physical site at which people could find their immediate necessities, including clothes, blankets, water, food, and cleaning products, no matter whether those supplies had been secured through the church or one of the non-profit organizations working out of the church. Further, by housing such a wide variety of social service organizations, the church helped to create an informal bridge between residents and their insurance companies and government relief agencies such as FEMA, SBA, and The Road Home Program. As a way to make ends meet, several of the people working in the nonprofit organizations housed at MQVN worked with government relief programs in the early months after the storm. This experience proved to be an important source of local knowledge that helped residents navigate the thick bureaucratic maze of insurance companies and government assistance. Given the difficulties even native English-speakers reported having in navigating these processes, the existence of this informal bridge was the only way many non-English speakers in this community were able to cope with the process at all.

In sum, the club goods provided by MQVN made social coordination possible prior to Katrina and fostered the quick return of this community after the disaster.

\section{c. Political action to protect their community}

[Father Vien] has a strong will...that determination, passion for the youth to take charge. He encouraged us to enter politics and be assertive. Me, I just want to live my own life... it's a Vietnamese characteristic; we want to live in peace. Politics [is] stress and lies, [but] Father Vien has asked us to take the lead... if you don't speak out, if you're not united [as a community] people don't respect your rights.

$-\mathrm{Ngoc}_{\text {Hoang }}{ }^{+}$

In addition to facilitating social coordination, the club goods provided by the MQVN church also facilitated political action in the early months following their return. In making its recommendations to the Bring New Orleans Back Commission, the Urban 
Land Institute (ULI) recommended that areas most seriously damaged from flood waters, particularly outlying areas that had little chance of recovery, would require "significant study" before rebuilding could commence (ULI 2005: 16). In its early release of key recommendations and later in its full report, the ULI $(2005,2006)$ recommended the creation of an agency called the Crescent City Reconstruction Corporation (CCRC) that would have the power to initiate eminent domain proceedings in areas deemed unviable. It was also in these reports that the ULI recommended that large portions of New Orleans East might be considered for conversion to "open space." In other words, the early days of the redevelopment planning process threatened to introduce greater uncertainty into the decision of displaced residents to return, increasing the likelihood that the sub-optimal outcome depicted in Figure 1 would obtain.

MQVN leaders and parishioners perceived the ULI recommendations as a direct threat to their ability to rebuild their community. The return of residents was viewed as a crucial first step in resisting this threat, but church and neighborhood leaders assumed that repaired homes would only go so far in dissuading city officials from razing the neighborhood if that was their intention. Community leaders bet that the early repair of the church and resumption of services would serve as powerful political tools in the effort to reclaim their community.

Father Luke: First, my priority was to bring the people back. And how we're going to do that? By way of fixing the church. The church is the center. The church is the anchor. The church is the center stage of communication. The church is where people find comfort, news and everything, updated news from the city. Because during that time, there was mixed messages from the city. [Were] they going to bulldoze this? ...What if we come back, we build, and they bulldoze it? What's the benefit of it? ... And so we decided to fix the church and set the church as the center stage of meetings, of uniting the people and so we fix up the church. ...And when we came back and rebuild, pulling our people in, people increased [from] two hundred, five hundred, eight hundred, a thousand, they won't force us out. So right now their plan is gone. 
Their plan is gone and they can't do anything about us. Other places, if they don't come back they going to bulldoze. But not this place.

In response to perceived threats from the city administration, the church pastors became increasingly savvy in their use of the various media to exert their own form of pressure. By photographing the assembled parishioners attending Mass and granting requests for interviews from any news organization that would tell their story, the church leadership was able to use the political symbolism of a repaired church filled with peaceful parishioners in their efforts to restrain the city administration.

Another tactic the church used to resist political pressure from the city was to bypass their authority and deal directly with service providers. After appealing to the city to restore electrical power with no success, Father Vien contacted the local power company Entergy directly. The Entergy representative explained that only half of the power stations were functioning and that most of that capacity had been directed to downtown and midtown for reconstruction. Yet, he also told Father Vien that the backbone connecting the power stations to New Orleans East was operational.

Father Vien: [I]n order to justify [and] divert power out here, we must justify that there are people here planning to receive it... [T]hey needed paying customers. ...I gave him pictures that we took of our people in Mass, first Mass. First Mass was 300 [people], second Mass was 800, third Mass we invited all the people from New Orleans, and we had more than 2000. So I had those pictures to show him. He said, "those I get. But now we need a list." And so we went and got what he asked. We called our people to put their names down and their addresses... So within one week, I went back to Lafayette, we went back to his office, I said, "Well, the city has 500 petitioners." So, the first week of November, we had power. And we were the only people with power.

The MQVN leadership also served as an effective political agent in securing a FEMA trailer park close to the church. The Archdiocese gave MQVN permission to 
establish the site on the land designated for the new senior housing project. Though negotiations with FEMA were relatively smooth, traversing the political hurdles erected by the city administration was another matter.

Father Vien: [We acquired permission from FEMA] on the 19th of October. We got the legal [documentation], and then we did the paperwork and brought it to the Mayor's office. We had our people call ... the Mayor. We had the Archdiocese in the discussion. The Mayor refused to sign it. He refused to sign it and I was so... [gesture indicating anger]. [T] hey had to bring it up at the [Bring New Orleans Back] Commission's meeting on ...Monday [November $21^{\text {st }}$. And so I called the Archbishop, because he was on the Commission. So I called the Archbishop and told him that unless the Mayor signed it on that day, we will set up a tent city because my people are living in moldy homes waiting for that. And so...that evening, the Archbishop called me and said, he said that he did it. [The Mayor] signed it. [But FEMA never received the signed documentation from the Mayor's office.] ...So I called the Archbishop and asked him to contact the Mayor and have the Mayor fax it to his office. ...But nothing moved for a whole week. And so I . . finally when I realized what they were doing, I called them again and I said that Monday, "if it doesn't happen, that [tent] city's going up."

Father Vien's threat to erect a tent city, (something the Mayor's office did not want to see as cold weather was approaching), was credible. They had permission from the Archdiocese to use the land adjacent to the church and plans were under way to purchase heaters and other supplies for the tents.

Father Vien announced their plans at a City Council meeting. ${ }^{24}$ Understanding the racial dynamics in New Orleans politics, Father Vien wondered aloud to the Council whether the resistance they were facing from the city administration was racially motivated.

Father Vien: The Mayor sent his people out to Atlanta, Dallas, Houston, and invited people to return. And so the question we raised at that time was that he 
sent his people out to invite the evacuees to return. We are here already. And yet, he has impeded our return... And so the question is, is it racial? That's the question. Is it because we are not of the right color? And so a few of [the Council members] caught up on that and then came out [to the community] and some senators came out here. Hillary Clinton and Mary Landrieu... came to this place... That was a Sunday, they called the FEMA, the head of FEMA right after they left here. And that person was able to reach the Mayor that day. The next day, Senators Clinton and Landrieu were going to see the Mayor... Only then were we able to come in.

Though the church had secured electrical service and a FEMA trailer site, and the rate of return was high relative to other neighborhoods, the community still faced another major hurdle. Faced with massive waste removal issues, the city administration resurrected plans to locate a landfill in an environmentally vulnerable area adjacent to the MQVN community. According to an agreement between Waste Management and the City of New Orleans, twenty-two percent of the revenues from the landfill would go directly to the city if the site was located within the city limits. ${ }^{25}$ The placement of the landfill would scuttle the church's plans for a senior housing complex and Viet-Town. Though the community had seen impressive rebound in terms of returning residents, the MQVN leadership saw the city's landfill initiative as a threat to the community's long-term viability. Thus all the resources that had been going into the community planning process pre-Katrina were now diverted to the landfill issue.

The primary goal of the church and civic leadership was to mobilize the community to demonstrate against the landfill, but the language barrier and a history of political insularity promised to stand in the way. At the same time, there was growing concern that the neighborhood youth were at significant risk, given the desperate state of the public schools and a dearth of organized youth activities since the storm. The proposed solution to both problems was the creation of VAYLA (Vietnamese-American Youth Leadership Association). By deploying the bilingual skills and more "Americanized" taste for political activism among teenagers and young adults, VAYLA played a central 
role in coordinating demonstration efforts, connecting with local and national environmental and community rights organizations, and eventually defeating the landfill initiative. One adult organizer remarked that their success in defeating the landfill offered a paradigm for how they should proceed with their other community development efforts.

After Katrina, the need for the church to serve as a catalyst for political resistance became clearer. Given the opposition the city administration had to rebuilding in the area, residents would have had little chance acting in isolation. The MQVN leadership provided the capacity to organize and resist political pressure to abandon the community.

\section{Conclusions}

The analysis presented here addresses the particular question of how it is that this neighborhood, even in the absence of abundant financial resources, rebounded more robustly than other communities facing similar conditions. By providing a bundle of club goods that allowed the members in this community to create what amounts to a "second homeland" and the coordination capacity to withstand a physically and politically inhospitable environment, the MQVN church has facilitated a level of social cooperation that has been difficult for many other communities to achieve.

In particular, because the MQVN church provides club goods which allow parishioners to create an ethnic-religious-language community, its members who would otherwise be disconnected and marginalized in the dominant culture can instead lead productive and connected lives; or in other words, they can exercise their agency more effectively. Because the church provides an organizational structure that facilitates complex social coordination, an individual's decision to return to a post-disaster context is less likely to be an isolated choice; or again, the agency the individual deploys under such circumstances is rendered more effective. Because that structure also facilitates political action, the individual's resistance to political threats is combined with the resistance of others; and once again, his or her agency is again rendered more effective. 
Beyond the specific question of how this community executed such a successful recovery, this case contributes more generally to our understanding of what role club goods can play in connecting individual agency to overall patterns of social coordination. The existing literature demonstrates that the religious provision of club goods can help explain the evolution of social institutions (Kuran 2001; Ekelund et al. 1996) and can render intelligible behavior that might otherwise defy explanation (Iannaccone 1992, 1994; Berman 2000, 2003). This study adds to that literature by highlighting how the church provision of club goods renders individual agency more effective in achieving social outcomes.

In addition to contributing to the literature on the provision of club goods by religious organizations, this analysis also complements the literature examining the role social capital plays in post-disaster contexts (Beggs et al. 1996a, 1996b; Hulbert et al. 2001). While much of the existing literature focuses on how individuals deploy their social networks to meet the immediate challenges of a natural disaster, this analysis fills an important gap by examining the role socially embedded resources (in this case club goods) can play in long term recovery of an entire community. In doing so, this study makes a contribution to the burgeoning literature exploring issues of agency and structure in the post-Katrina recovery process (Colten 2006; Elliott \& Pais 2006; Henkel et al. 2006; Hartman \& Squires 2006; Herring 2006).

\footnotetext{
${ }^{1}$ Portions of the Lower Ninth Ward are well-known examples. Further, many neighborhood blocks within New Orleans East, but outside the particular community examined here, have seen little rebuilding.

2 See Dateline "Postcard from New Orleans," aired June 15, 2007. http://video.msn.com/v/us/fv/msnbc/fv.htm??g=a379983e-f187-4b40-af48$\underline{77178 f 4330 \mathrm{a} 4 \& \mathrm{f}=00 \& \mathrm{fg}=\mathrm{email}}$
}

${ }^{3}$ Coyne (2007) reaches a similar conclusion when discussing the prospects of the U.S. successfully exporting democracy. As he finds, efforts at nation building have only succeeded in exporting democracy to states that had democratic traditions. 
${ }^{4}$ In 2008, however, Anh "Joseph" Cao, who has close ties to this community, was elected to represent Louisiana's 2nd congressional district which contains almost all of the city of New Orleans.

${ }^{5}$ It is worth noting that the effort to build the church was driven from the ground up. As Bankston \& Zhou (2000: 460) observe, "...this church was not established from above by a clerical hierarchy, but it came into existence as a consequence of the desires and efforts of lay participants." This detail is significant in that it demonstrates that this community has had a history of achievement when it comes to community development.

${ }^{6}$ According to Census 2000 Summary File 3 (SF-3), home ownership rates rose from 2.8\% in 1980 to $27.8 \%$ in 1990 , to $39.3 \%$ in 2000 . In 1990, the median income in the MQVN neighborhood, Orleans Parish and Louisiana were $\$ 17,044, \$ 18,477$ and $\$ 21,949$, respectively. By 2000, median incomes were $\$ 24,955, \$ 27,133$, and $\$ 32,566$, respectively. NB: The Census track 17.29, used as the point of comparison for 1980 and 1990, is broken up into tracks 17.41 and 17.42 in the 2000 Census.

${ }^{7}$ According to the 1990 Census, this community was 87\% Catholic (Bankston \& Zhou 2000).

${ }^{8}$ The other Vietnamese Catholic churches in the area provided a higher proportion of English language services to Vietnamese language services, for example.

${ }^{9}$ This observation is also made in Zhou \& Bankston (1994).

${ }^{10}$ See Chamlee-Wright $(2007,2008)$ for a review of how regime uncertainty can distort the return calculus of displaced residents.

${ }^{11}$ We assume that players would want to return if they could recreate the community that they had before the disaster. If this were not true in at least some cases then disasters which displaced residents would always result in depopulation.

${ }^{12}$ Of course there are costs to both decisions and so payoffs should be thought of as net payoffs.

${ }^{13}$ See Cornes and Sandler (1996) for an excellent overview.

${ }^{14}$ See Congleton (2005) for a notable exception.

${ }^{15}$ The research team deployed both purposive sampling and random sampling within the MQNV neighborhood, the FEMA trailer site adjacent to the church, and specific 
demographic groups to ensure a representative diversity in income, age, gender, and language competency within the sample. The advance team setting up the interviews determined whether a Vietnamese interpreter would be required. Once a round of interviews was completed, the audio files were translated and transcribed. After the English language portions of the audio files were transcribed, another interpreter translated and transcribed the original Vietnamese language on the audio files to ensure accuracy. The transcripts were then coded for themes and patterns, including those discussed here.

16 Whenever possible, we protect the identity of the interview subject. Names with the " + " superscript are pseudonyms. Because of the nature of their commentary and their profile within the community, it would be impossible to obscure the identity of the pastors of the MQVN church. In such cases, we obtained permission to use the subject's real name.

${ }^{17}$ Alone, that payoff may or may not have been sufficient to make returning the dominant strategy (i.e. $\delta+\theta>\beta$ ). In the case of the MQVN community, however, the church also provided club goods which lowered the uncertainty surrounding the intentions of others to return. This will be explicitly discussed in subsequent sections.

${ }^{18}$ Iannaccone (1994) argues that a religious group can avoid free riding by increasing strictness, but also points out that too much strictness (say, strictly limiting social interaction with people outside the religious group) can be inefficient if it severely restricts economic opportunity. Research on the deployment of social capital in the New Orleans East Vietnamese community, such as Zhou \& Bankston (1994), suggest that strictness in this case (holding youth close to the Vietnamese community) cuts off social opportunities within the poor minority community but expands economic opportunity in the dominant affluent culture. Thus, in this particular context, strictness and economic opportunity are not at odds.

${ }^{19}$ Some members of the local business community were able to articulate the importance their business had for the overall redevelopment process. For example,

Nhu Pham+: Before I came back, I was thinking that we were just going to open up the business no matter what. Because the people only come back if there are businesses providing supplies and other basic services. If there were none, the people wouldn't dare come back. I open up the business just to keep this place alive, I only want to make sure that we don't have any net loss. The main purpose is to keep the community alive.

${ }^{20}$ Though most people cited personal qualities Father Vien possessed as important in his ability to lead, many also said that it was the position, not the man, that mattered mostand that they would have abided by the wishes of any priest, not just Father Vien. 
${ }^{21}$ Virtually every member of the MQVNN community we interviewed reported that the local church leadership was important to the community's rebuilding success. Almost every interview makes reference to the authority vested within the priesthood and/or the personal leadership qualities of the parish priests. In addition to the authority effect, approximately one-third of the interview subjects described a distinct signaling role church leadership played in attracting people back.

${ }^{22}$ The MQVN Community Development Corporation was established following Katrina to address this concern. See http://www.mqvncdc.org/ for information of this organization.

${ }^{23}$ One of the directors at the CDC reports that familiarizing the community with the functions of her office has been a bit of a challenge. Members of the community more often than not assumed that she worked for the church. In response, she would say "'I don't work for the church,' and then having explained what the CDC is and all that stuff, they [would say], 'okay, so you're with the church?' and I'm like, 'Yeah, I'm with the church.'"

${ }^{24}$ Father Vien reports that Council-woman Cynthia Hedge-Morrell had been a vocal advocate for their cause, but her advocacy alone was not enough to gain the cooperation of the city administration.

${ }^{25}$ See Dunne, Mike (2006) "Failure to Halt Landfill Doesn't Stop Activists," The Advocate [Baton Rouge] 28 April, Main ed: B2, and Russell, Gordon (2006) "Chef Menteur Landfill Testing Called a Farce," New Orleans Times-Picayune 26 May, National 1.

\section{References}

Bankston, Carl L. III and Min Zhou. 1995. "Effects of Minority Language Literacy on the Academic Achievement of Vietnamese Youths in New Orleans." Sociology of Education 68: 1-17. 1996. "The Ethnic Church, Ethnic Identification, and the Social Adjustment of Vietnamese Adolescents." Review of Religious Research 38: 18-37. 2000. "De Facto Congregationalism and Socioeconomic Mobility in Laotian and Vietnamese Immigrant Communities." Review of Religious Research 41: 453-470.

Beggs, J., Haines, V. \& Hurlbert, J. 1996a. "Situational Contingencies Surrounding the Receipt of Social Support." Social Forces 75:201-22. 1996b. "The Effects of Personal Network and Local Community Contexts on the Receipt of Formal Aid during Disaster Recovery." International Journal of Mass Emergencies and Disasters 14: 57-78. 
Berman, Eli. 2000. "Sect, Subsidy, and Sacrifice: An Economist's View of Ultra-Orthodox Jews." Quarterly Journal of Economics 115:905-953.

2003. "Hamas, Taliban and the Jewish Underground: an Economist's View of Radical Religious Militias." National Bureau of Economic Research, NBER Working Paper No. 10004.

Bohrer, Becky. 2007. “New Orleans' Lakeview Area Could be Bellwether for Recovery." Associated Press, May 15

http://www.nola.com/newslogs/topnews/index.ssf?/mtlogs/nola topnews/archives/ 200612 27.html

BondGraham, Darwin (2007) “The New Orleans that Race Built: Racism, Disaster, and Urban Spatial Relationships," Souls: a Critical Journal of Black Politics, Culture $\mathcal{E}$ Society, 9(1):4-18.

Bosman, Fred and Henk Bakker, Pieter de Wit, Eric Noorthoorn, Robert Fullilove and Mindy Fullilove (2007) "Envisioning 'Complete Recovery' as an Alternative to 'Unmitigated Disaster,'” Souls: a Critical Journal of Black Politics, Culture \& Society 9(1):4-18.

Buchanan, James. 1965. “An Economic Theory of Clubs.” Economica 32(125): 1-14.

Caplan, Nathan, Marcella Choy and John Whitmore. 1989. The Boat People and Achievement in America. Ann Arbor, MI: University of Michigan Press.

1992. "Indochinese Refugee Families and Academic Achievement." Scientific American 266: 36-42.

Chamlee-Wright, Emily. 2007. "The long road back: signal noise in the post-Katrina context." The Independent Review 12 (2): 235-59.

2008. "Signaling effects of commercial and civil society in post-Katrina reconstruction." International Journal of Social Economics 35 (8): 615-626

Chamlee-Wright, Emily and Virgil Storr. 2007. "Community Resilience in New Orleans East: Deploying the Cultural Toolkit Within the Vietnamese-American Community." The Mercatus Center Working Paper Series.

Colten, Craig E. 2006. "Vulnerability and Place: Flat Land and Uneven Risk in New Orleans." American Anthropologist 108: 731-734.

Congleton, Roger D. 2005. "“Ethnic Clubs, Ethnic Conflict, and the Rise of Ethnic Nationalism" in Breton, Galeotti, Salmon \& Wintrobe (eds.) Nationalism and Rationality. Cambridge University Press.

Coyne, Christopher. 2007. After War: The Political Economy of Exporting Democracy. Stanford University Press.

Cornes, Richard and Todd Sandler. 1996. The Theory of Externalities, Pubic Goods and Club Goods, $2^{\text {nd }}$ Edition. Cambridge University Press.

Dasgupta, Indraneel and Ravi Kanbur. 2005a."Community and Anti-Poverty Targeting." Journal of Economic Inequality 3: 281-302.

2005b. "Bridging Communal Divides: Separation, Patronage, Integration" in Christopher Barrett (ed.) The Social Economics of Poverty: On Identities, Groups, Communities and Networks. London, Routledge. 
2007. "Community and Class Antagonism." Journal of Public Economics 2007: 18161842.

Dyson, Michael Eric. 2006. Come Hell or High Water: Hurricane Katrina and the Color of Disaster. New York: Basic Civitas Books.

Ekelund, Robert, Robert Tollison, Gary Anderson, Robert Hebert, and Audrey Davidson. 1996. Sacred Trust: The Medieval Church as an Economic Firm. New York: Oxford University Press.

Elliott, James R. and Jeremy Pais. 2006. "Race, Class, and Hurricane Katrina." Social Science Research 35: 295-321.

Erickson, Kai. 1994. A New Species of Trouble: the Human Experience of Modern Disasters New York: WW Norton.

Hartman, Chester and Gregory D. Squires, eds. 2006 There is No Such Thing as a Natural Disaster: Race, Class and Hurricane Katrina. New York: Routledge.

Henkel, Kristin E., John F. Dovidio, and Samuel L. Gaertner. 2006. "Institutional Discrimination, Individual Racism, and Hurricane Katrina." Analyses of Social Issues and Public Policy 6: 99-124.

Herring, Cedric. 2006. "Hurricane Katrina and the Racial Gulf." Du Bois Review: Social Science Research on Race 3:129-144.

Haines, David, Dorothy Rutherford, and Patrick Thomas. 1981. "Family and Community among Vietnamese Refugees." International Migration Review 15: 310-319.

Hurlbert, J., Beggs, J. \& Haines, V. 2001. "Social Capital in Extreme Environments." In Social Capital: Theory and Research edited by N. Lin, K. Cook, and R. Burt, Pp. 209231. New York: Aldine De Gruyter.

Iannaccone, Laurence R. 1992. "Sacrifice and Stigma: Reducing Free-riding in Cults, Communes and Other Collectives." Journal of Political Economy 100: 271-291. 1994. "Why Strict Churches are Strong." The American Journal of Sociology 99: 11801211.

Kibria, Nazli. 1994. "Household Structure and Family Ideologies: The Dynamics of Immigrant Economic Adaptation among Vietnamese Refugees." Social Problems 41: 81-96.

Klinenberg, Eric. 2003. Heat Wave: A Social Autopsy of Disaster in Chicago Chicago: University Of Chicago Press.

Kuran, Timur. 2001. “The Provision of Public Goods under Islamic Law: Origins, Impact, and Limitations of the Waqf System." Law \& Society Review 35: 841-898.

Mill, John Stuart 1909[1848]. The Principles of Political Economy William J. Ashley, ed. London: Longmans, Green, \& Co.

Olson, Mancur. 1965. The Logic of Collective Action. Cambridge, MA: Harvard University Press.

Peacock, Walter, Betty Morrow, and Hugh Gladwin (1997) Hurricane Andrew: Ethnicity, Gender, and Sociology of Disasters. Miami: International Hurricane Center.

powell, john a., Hasan Kwame Jeffries, Daniel W. Newhart, and Eric Steins (2006) in Hartman \& Squires (eds.) 
Rumbaut, Ruben and Kenji Ima. 1998. Between Two Worlds: Southeast Asian Refugee Youth in America Boulder: Westview Press.

Samuelson, Paul. 1954. "The Pure Theory of Public Expenditure." Review of Economics and Statistics 36: 387-89.

Urban Land Institute. 2005. “Executive Summary of Key Recommendations: A Strategy for Rebuilding New Orleans, Louisiana."

http://www.uli.org/Content/NavigationMenu/ProgramsServices/AdvisoryServices/ KatrinaPanel/exec summary.pdf 2006. "New Orleans, Louisiana: A Strategy for Rebuilding." http://www.uli.org/AM/Template.cfm?Section=Search\&section=Reports PDF files \&template $=/ \mathrm{CM} /$ ContentDisplay.cfm\&ContentFileID $=22500$

Wisner, Ben, Piers Blaikie, and Terry Cannon. 2004 At Risk: Natural Hazards, People's Vulnerability and Disasters. London: Routledge.

Zhou, Min and Carl Bankston. 1994. "Social Capital and the Adaptation of the Second Generation: The Case of Vietnamese Youth in New Orleans." International Migration Review 28: 821-845.

1998. Growing Up American: How Vietnamese Children Adapt to Life in the United States. New York: Russell Sage Foundation. 